\title{
Development of a Field-Based Chemistry Experiment Teaching Model to Strengthen Pre-Service Teachers' Competence for Teaching Chemistry Experiments
}

\author{
Sung Woo Bae \\ Daegu Dongbu Highschool, Daegu, 41074, Republic of Korea \\ psw311@nate.com \\ Jae Hwan Lee | ORCID: 0000-0002-9562-5526 \\ Corresponding author, \\ Department of Chemistry Education, Kyungpook National University, \\ Daegu, 41566, Republic of Korea \\ deresa22@knu.ac.kr \\ Jongseok Park \\ Corresponding author, \\ Department of Chemistry Education, Kyungpook National University, \\ Daegu, 41566, Republic of Korea \\ parkbell@knu.ac.kr
}

Received: 30 July 2021 | Revised: 26 October $2021 \mid$

Accepted: 4 November 2021

\begin{abstract}
The FCE (field-based chemistry experiment) model was developed to cultivate preservice science teachers' ability to teach chemistry experiments in secondary classrooms. We describe the process of developing the FCE model and student activities via feedback from experts and analysis of the implemented program. This study evaluated the effectiveness of implementing the FCE model with $5^{8}$ pre-service science teachers to examine how this model impacts on the role of the instructor and students. Implementation impact was examined by analyzing qualitative data from surveys and observations of student activities. The FCE model minimized the role of the instructor
\end{abstract}


by using flipped learning and cooperative learning, which enabled learners to construct class contents by themselves with topics aligned to the secondary science curriculum. Findings suggest the FCE model supports pre-service science teachers to acquire both knowledge and practical skills related to conducting and teaching experiments. Implications for pre-service science teacher preparation are discussed.

\section{Keywords}

field-based - flipped learning - cooperative learning - pre-service teacher

$$
\text { 초록 }
$$

대학교육에서 일반화학실험은 이공계열 학생들의 기초 교양교육을 위해 필수적으로 수강하여 화학의 기초를 배우도록 한다. 과학 교사를 양성하기 위한 사범 대학에서의 일반화학 실험 과목은 필수 과목으로서 일반 자연 계열 학과에서 가르치는 일반화학실험과는 차별성을 두어야 할 필요가 있 다. 본 연구의 목적은 예비교사들의 화학 실험 지도 역량을 강화하기 위해 수업 모형을 개발하고 그 효과를 알아보는 것이다. 이를 위해 FCE(field-based chemistry experiment)모형 개발, 학생 활동 양식 개발, 전문가 검토, FCE 모형 적용, 자료 수집, 자료 해석의 과정을 거쳤다. 그 결과 현장 기반의 일반화학 실험 모형'을 뜻하는 $\mathrm{FCE}$ 를 개발하였다. $\mathrm{FCE}$ 는 교수자의 역할을 최소로 하 고, 중등 교육 과정과 연계한 실험 주제로 학습자가 스스로 수업 내용을 구 성하여 학생 상호간의 협동을 통해 학습이 이루어질 수 있도록 플립 러닝 과 협동 학습을 적용하였다. 또한 실험 수업에서 학생들을 관찰하고 평가 하며 지도하는 활동을 통해 실험 수업에서 교사의 역할을 체득하도록 하였 고, 과학 교사로서 화학 실험 수업을 지도하는데 필요한 일련의 과정들을 직접 수행해 볼수 있도록 구성하였다. 이를 $\mathrm{K}$ 대학교 사범 대학에 개설된 일 반화학실험 과목을 수강하는 예비 교사 58 명에게 적용하여 온라인 학습 관 리 시스템 (LMS)에 탑재된 활동 결과물과 수업 중 교수자의 관찰 일지 및 면 담지와 설문지를 수집하여 분석하였다. 분석 결과, $\mathrm{FCE}$ 모형을 통해 예비 과 학교사들은 실험 및 실험 지도와 관련된 지식, 실제적인 실험 수행 및 실험 지도 능력을 습득한 것으로 나타났다.

\section{1 \\ Introduction}

General chemistry and laboratory courses as a required liberal arts education cover basic concepts and essential contents of chemistry for science majors 
(Hawkes, 1992). Experimentation is fundamental to science, especially in chemistry. A study shows that many students believe that conducting experiments via hands-on activities is the best way to learn (Lazarowitz, Hertz-Lazarowitz, \& Baird, 1994). Data shows that it is much more effective to divide students into groups, when conducting experiments in a laboratory setting, rather than an individual activity, resulting in a higher learning effect. (Hofstein, 2004). Moreover, students make a connection between their everyday life and science through experiments (Yurumezoglu \& Oguz-Unver, 2011). Hawks (2007) points out that introductory level chemistry courses for engineering students need to be drastically revised to meet the needs of students. He has previously made similar claims in the research for life science majors (Hawks, 1989). The survey conducted on the students with a major in life science who were taking general chemistry course at a U.S. University reveals that the course should focus more biological perspective that are related to chemistry than the general chemistry. In fact, the students who had taken such course had a higher academic achievement (Schnoebelen \& Towns, 2018). Therefore, teaching general chemistry or general chemistry experiment courses at universities need to be adjusted depending on the learners' major.

A general chemistry experiment is a mandatory course for the students in a science teacher training program as well as in a college of education. The most important factor in a teacher training program is actual teaching experience, which can give valuable experience to pre-service teachers (Schoon \& Sandoval, 1997). Two universities in the United States analyzed their chemistry teacher training programs and the results showed that teachers who had gone through the program felt there was a discrepancy between what they learned in the program and the reality of teaching (Pak et al., 2001). Researchers in education and students all agree that pre-service science teachers need in-class teaching experience before becoming teachers. Field experience at an actual school laboratory during undergraduate courses provides pre-service science teachers practical experience (Weld \& French, 2001). Lee and Lee (2016) emphasized that pre-service science teachers need practical training before teaching practice. Some studies based on teaching-learning materials such as lesson plans and activity sheets written by pre-service teachers have shown that it is necessary for pre-service science teachers to gain pedagogical knowledge and experience the challenges of the actual educational field (Lee \& Im, 2011; Noh, Choi, \& Chung, 2020; Yang, Lee, \& Noh, 2014).

The main goal of the teacher training program is to develop qualified professional teachers (Kim \& Lee, 2006). In particular, the curriculum for training science teachers should not only focus on scientific content knowledge but should be connected to developing professionalism with practical knowledge (Bales, 2007; Kim \& Shim, 2009; Shim, 2010). Pre-service chemistry teachers 
also need a variety of competence when teaching chemistry in a school setting. Therefore, it is necessary to develop the competence required in the school field in teacher training institutions (Rusmansyah et al., 2019). In this aspect, the Project-Based Learning (PBL) model and the inquiry model are used to foster competences such as critical thinking skills and pre-service chemistry teachers' self-efficacy (Rodriguez-Becerra et al., 2020). Studies using a computational chemistry module have been shown to develop pre-service teachers' technological pedagogical science knowledge and to increase pre-service teachers' evaluation ability in inquiry-based chemistry laboratories (Ferk Savec \& Wissiak Grim, 2017; Zemel, Shwartz, \& Avargil, 2021). Moreover, studies have been conducted to improve pedagogical content knowledge (PCK) and content knowledge (CK), which are essential for chemistry teachers (Mavhunga, 2014; Wheeldon, 2017; Widhiyanti et al., 2017). As such, it is very important for teacher training institutions to equip pre-service chemistry teachers with various competences.

\section{Purpose of This Research}

This study directly addresses this issue by using a model planned and implemented in connection with a school site to equip pre-service chemistry teachers with experimentation capacity and class management competence. In addition, the preparatory teacher training curriculum plays a very important role in shaping beliefs and qualifications as science teachers (Kim et al., 2010). However, it has been pointed out that curriculum for pre-service science teachers lacks a connection with the actual school environment and an understanding of the actual teaching scene and does not strengthen pre-service teachers' motivation to enter the teaching profession (Cho, 2004). Given these points, for pre-service science teachers to develop competence in leading chemistry experiments, a curriculum in conjunction with a school site is required, and it is necessary to operate an activity-oriented general chemistry experiment lab.

In this study, we developed and applied a model that we called the fieldbased chemistry experiment (FCE) model to a science teacher training curriculum so that pre-service science teachers can develop competence to instruct chemistry experiments. The word "field" in general is used in various ways, but in this study, it refers to the school setting that pre-service teachers will face when they become teachers. The FCE model was designed based on flipped learning and cooperative learning with experiment-based subjects in connection with the secondary education curriculum to empower pre-service science teachers in real school settings. This model focuses on performing a series of activities that can be experienced as both a student and teacher, which helps 
them to learn actively. The FCE model was developed to enhance pre-service teachers' ability to guide chemistry experiments, which is necessary for classroom teachers. Pre-service science teachers will be able to apply what they have learned through FCE in actual school laboratory environments. The FCE model was designed to have science teachers perform a series of courses that are directly required for science teachers to learn how to implement chemistry experiments.

Conventional courses about general chemistry experimentation have tended to focus on learning basic experimental techniques related to chemical experiments and identifying general chemistry-level experimental principles through experimentation. However, it is important for pre-service teachers to have practical knowledge about instructing based on practical work rather than simply learning experimental techniques or process skills. This research reports on the development and implementation of this FCE model with preservice science teachers in a university level experimental chemistry course. This study seeks to answer the following research questions:

1. What does the FCE model look like when applied in university level general chemistry class for pre-service science teachers?

2. What are students' general perceptions about the model and stepwise activities experienced during the FCE model with regards to their learning about content and pedagogy?

3. What are some benefits and limitations associated with implemented this model to prepare pre-service science teachers?

\section{$3 \quad$ Research Background Supporting Model Development}

\subsection{Flipped Learning in Experimental Chemistry Classes}

Flipped learning, which has recently been used in the classroom, is an alternative to traditional education methods in which learners use online content such as videos uploaded by instructors for learning before students come to the class and learner-oriented activities such as discussions and team activities (Fautch, 2015; Kim, 2014; Romero-García et al., 2018; Toqeer, 2013). Flipped learning is currently being applied in a variety of ways, from elementary and secondary schools to universities (Seery, 2015). In recent years, it has been actively used by domestic and foreign universities as an educational method for the innovation of university education (Bokosmaty, Bridgeman, \& Muir, 2019; Choi \& Kim, 2015; Kim, Chun, \& Choi, 2014; Lucena et al., 2020; Teo et al., 2014). 
Science classes using flipped learning have been shown to have a positive influence on academic achievement and scientific attitudes (Jeon \& Yoon, 2016). They have also been applied in pre-service science teacher education (Jeon \& Yoon, 2016), and there have been various studies on flipped learning at school sites (Lee et al., 2014; Lee, 2013). Therefore, giving pre-service science teachers experience and practice in flipped learning can be of great help in applying and using it in the field. If flipped learning techniques are applied in preparatory science teacher education, they will be effective in teaching what the preparatory science teacher needs to become a teacher on their own. To introduce flipped learning into the science teacher preparation education, it is appropriate to take activity-oriented experiment-based classes rather than theory-based lecture-style classes. Because actual experiment-based activities are centered on learners rather than instructors, there are many similarities to flipped learning. Therefore, when applying flipped learning to a chemistry experiment class, there will be less sense of alienation between instructors and learners due to similarities in class style.

\subsection{Benefits of Cooperative Learning}

Previous studies focusing on students' cooperative learning have argued the benefit of performing pre-learning activities, engaging students in studentcentered activities, such as problem solving and cooperative learning, to engage in real-world experiment-based classes (Davies, Dean, \& Ball, 2013; Dixon, 2010; Jamaludin \& Osman, 2014). From a constructivist perspective that emphasizes student-centered teaching and learning theory, cooperative learning is aimed at encouraging students to actively participate in learning and learn on their own (Munir et al., 2018; Sharan, 2010). Research on cooperative learning in schools, especially the jigsaw model, has long been conducted to learn about academic achievement by applying it to science classes (Hwang \& Park, 2011; Park \& You, 2001; Choi \& Ahn, 2001). Having pre-service science teachers engage in cooperative learning activities, such as jigsaw activities, can be useful when they become teacher as they may incorporate these activities in their own classrooms.

Field-Based Chemistry Experiment (FCE) Model Overview

The FCE model was designed using flipped learning and cooperative learning to teach experiment-based subjects linked to the secondary curriculum so that pre-service science teachers could strengthen their competence in an actual school setting. Flipped learning and cooperative learning were used in the FCE 
model to ensure that students learn through collaboration by organizing their own class agendas, thereby reducing the role of instructors to a minimum, and developing experiment topics associated with secondary education courses. This allows the students in the program to assume the role of the teacher through activities involving making observations, conducting evaluations, and giving instruction to other students throughout the lab experiment class. In this section, we describe the research that supported the development of the FCE model, including a focus on flipped learning and cooperative learning strategies.

In flipped learning contexts, students generally use pre-provided videos, printouts, and more to learn individually and later work together through classes in school. Experiment-based classes have time constraints because students must learn about theory and perform experiments. Hence, in the FCE model, by applying flipped learning, "students in class" learn the theory related to the experiment and the background knowledge necessary to perform the experiment before the experiment class and are then organized into groups to perform the experiment in the lab.

With this configuration, it is possible to conduct experiments and have sufficient class time for discussion. The students in charge create pre-learning materials and select the content of the experiment. When creating pre-learning materials, students do not just use the various materials provided by instructor, but rather reconfigure them themselves. The instructor observes and guides the students during the class. The jigsaw learning method is used as cooperative learning. Students in class perform professional group activities during group work. Students in the group choose one of four areas, experimental principles, experimental safety, experimental courses, or experimental results, become knowledgeable in that field, and participate in expert group activities. Students in class review what they learned previously in expert group activities and discuss what they do not understand yet through peer talks.

After expert activities, each expert returns to their original group and performs the actual experimental activities, shares roles, cooperates to conduct experiments, prepares experimental apparatus and materials, and records experimental results. When questions or problems arise during the experiment, they are resolved through inter group discussion and Q\&A with students in charge or instructor. By granting each individual a role in group work through professional group activities, students participate in the lab class responsibly and increase interdependence through prevention of free riding and through effective argumentation. In the experiments, each expert comes together to work together to solve the experimental challenges. 
This research was conducted as a program development and implementation study to determine the effectiveness of implementing a flipped classroom teaching strategy with collaborative learning activities with pre-service chemistry teachers in a university general chemistry course. A model for cultivating the teaching ability of pre-service teachers for chemical experiments was developed through a review of previous studies and literature analysis and was revised and supplemented through a workshop consisting of five experts in science education. The developed model was applied to $5^{8}$ pre-service science teachers in the general chemistry experiment class opened for pre-service science teachers. The research was conducted as a participant observer study with the course instructor serving as both a participant in the course and as a researcher. Learner outcomes such as class materials, preliminary reports, result reports, class observation reports, and data such as questionnaires and interviews were collected. This study explores both qualitative and quantitative data collected from pre-service teachers as they engaged in the FCE course to report on their overall impressions about the effectiveness of this model for learning both content and pedagogy. In the sections that follow, information about model development direction setting and model development, participants, and data collection and analysis methods are shared. The overall process of the developing and application of the FCE model is shown in Figure 1 below.

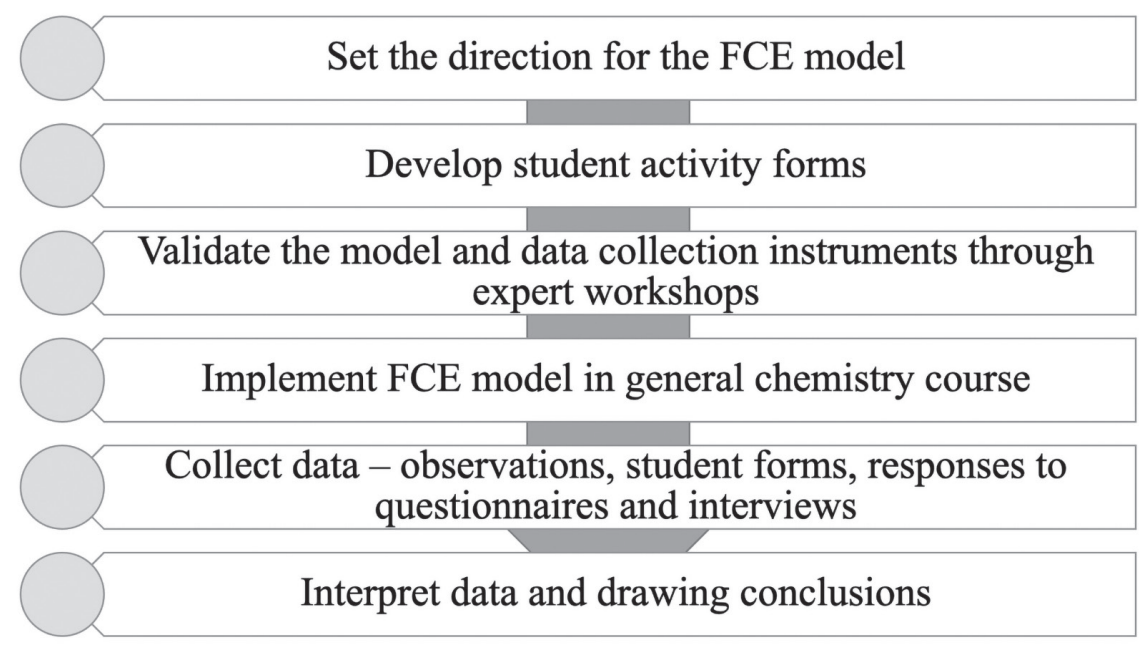

FIGURE 1 Process of the developing and evaluating FCE model instrument 


\subsection{Development Direction Setting of the FCE Model and FCE Model Development}

The development direction of a field-based chemistry experiment class model was set based on flip learning and cooperative learning teaching strategies so that pre-science teachers could actively learn. Based on this, the FCE model was developed so that a series of activities performed by teachers in the educational field can be performed to cultivate the pre-service science teachers' ability to teach chemistry experiments.

\subsection{Development of Data Collection Instruments}

To help pre-service science teachers carry out each step of the activities on their own, five different types of student activity form templates were developed: 1) assignment guide templates, 2) instructional materials template, preliminary report template, result report template, and class observation template. These activity form templates were developed to support students to engage in the FCE model activities using a uniform approach. These templates supported students to develop their materials for the class and provided researchers with comparable data sources.

The forms were developed and then revised through discussion with members from an expert panel of two professional science educators and three science education doctoral students. Student questionnaire was developed consisting of questions asking about the strengths and points of improvement of the FCE model. The expert panel members reviewed the student activity forms and student questionnaires designed to collect information about students' experiences in the FCE model taught course. The revised templates were used in the implementation of the FCE model. More details are provided below about the student questionnaires are offered below.

\subsection{Research Participants}

This study was conducted at a college of education in a large university in Korea with students engaged in a general chemistry lab course required for teacher certification. The general chemistry experiment model developed for pre-service science teachers was implemented with physics, chemistry, biology, and earth science students who were required to take general chemistry lab courses in the College of Education at K university. This study was conducted with 58 students who were in 4 different classes for 100 minutes once a week for 15 weeks. One of the researchers directly participated in this research as an instructor of the courses. In this role, the instructor observed students' 
activities and collected their activity results and class recordings for data analysis and drawing conclusions

\subsection{Data Collection and Analysis}

The data collected to document the activities of the FCE model included the templates students use to record their experiences during 12 laboratory activities. These documents served as data for analyzing how pre-service teachers planned for teaching and learning during these 12 experimental chemistry labs. Data included forms completed by each group that included, analysis of secondary science education curriculum and textbook, teaching material development, preliminary reports, result reports, and class observation reports.

The curriculum and textbook analysis, teaching material development, and result reports were collected from the online learning management system (LMS) students uploaded before and after classes. The preliminary reports and class observation reports were collected in class in handwritten form. Unusual matters observed by the instructor during class were freely recorded in the instructor's class observation journal. However, as it was impossible to record the activities of all group members at the same time, the instructor focused attention on the activities of specific group members for each lab. In addition to these documents, researchers conducted interviews with pre-service chemistry teachers during a feedback process in which students reported their activity outcomes and during informal discussions during lab activities. Some students agreed to participate in face-to-face interviews outside of class so that their activities could be learned about more deeply. These interviews were conducted after obtaining consent. The interviews were recorded and then transcribed and organized for analysis. The interview data supported the interpretation of observations, document analysis, and questionnaire responses in this study. However, the interview data are not specifically described in this paper - rather we focused on using the interviews and open-ended responses to interpret student responses on the survey.

Finally, post-lab questionnaires was developed and implemented with participants to determine the effects and improvements of the FCE model after applying it. The questions in the post-lab questionnaire consisted of questions asking about the suitability, effects, and strengths of the FCE model. The questionnaire categories and sample items are shown in Table 1.

Qualitative data analysis was conducted on the student activity sheets and interview comments collected during the application of the FCE model by first dividing the data into two categories: experimental performance ability and 


\section{Survey sections Items for each section}

\begin{tabular}{|c|c|}
\hline ssessino the & $\begin{array}{l}\text { Q1: Do you think the general chemistry experiment class to } \\
\text { which the FCE model was applied realized "learner-centered } \\
\text { learning" well? } \\
\text { Q2: Do you think the general chemistry experiment class to } \\
\text { which the FCE model was applied implemented "flipped learn- } \\
\text { ing” well? } \\
\text { Q3: Do you think the general chemistry experiment class to } \\
\text { which the FCE model was applied implemented "cooperative } \\
\text { learning" well? } \\
\text { Q4: Do you think the general chemistry experiment class to } \\
\text { which the FCE model was applied was helpful in learning "chem- } \\
\text { istry lab instructional skills" well? } \\
\text { Q5: Do you think the general chemistry experiment class to } \\
\text { which the FCE model was applied was appropriate for a teacher's } \\
\text { education program? }\end{array}$ \\
\hline $\begin{array}{l}\text { The effects of } \\
\text { the FCE model } \\
\text { (Likert scale } \\
\text { responses and } \\
\text { open-ended } \\
\text { short response) }\end{array}$ & $\begin{array}{l}\text { Q6: Please indicate how helpful the following activity you } \\
\text { performed in your general chemistry lab class with FCE models } \\
\text { would help you learn the chemistry lab instruction skills required } \\
\text { as a science teacher. } \\
1 \text { Analyzing curriculum and textbook } \\
2 \text { Developing instructional materials } \\
3 \text { Preliminary experiment } \\
4 \text { Writing preliminary reports } \\
5 \text { Expert group activities } \\
6 \text { Group experimental activities } \\
7 \text { Writing result reports } \\
8 \text { Class instruction and writing observation reports } \\
\text { Q7: How do you expect the general chemistry lab class to which } \\
\text { the FCE model is applied to be helpful in guiding the lab class as } \\
\text { a field teacher in the future? }\end{array}$ \\
\hline $\begin{array}{l}\text { The strengths of } \\
\text { the FCE model } \\
\text { (open-ended } \\
\text { short response) }\end{array}$ & $\begin{array}{l}\text { Q8: Write freely about the merits of the general chemistry lab } \\
\text { class to which the FCE model was applied. }\end{array}$ \\
\hline
\end{tabular}


TABLE 1 Survey questions for FCE model (cont.)

\section{Survey sections Items for each section}

The improveQ9: Please write freely about the improvement points for the

ment of the limitations of the general chemistry class to which the FCE

limitations to model is applied.

the FCE model

(open-ended

short response)

TABLE 2 Collected data analysis framework

Domains Sub-domains

\begin{tabular}{|c|c|}
\hline \multirow{3}{*}{$\begin{array}{l}\text { Experimental } \\
\text { performance ability }\end{array}$} & Knowledge of experimental principles \\
\hline & Knowledge of laboratory safety \\
\hline & Operation skills of lab equipment \\
\hline \multirow{6}{*}{$\begin{array}{l}\text { Experimental } \\
\text { teaching ability }\end{array}$} & Ability to reconstruct the content of the experiments \\
\hline & Ability to improve experiments \\
\hline & Performance skills of preliminary experiments \\
\hline & Teaching skills \\
\hline & Student assessment skills \\
\hline & Ability to cope with unexpected situations \\
\hline
\end{tabular}

experimental teaching ability. These categories reflected the impact outcomes anticipated from implementing the model with students. Each of these two categories were further divided into sub-domains and collected data were reviewed, sorted, and categorized using this analysis framework (see Table 2). In addition, quantitative analysis was conducted on the questionnaire responses completed by student participants $\left(N=5^{6}\right)$. This data was used to understand and support findings from the qualitative analysis. 
TABLE 3 Six key elements of the Field-based Chemistry Experiment (FCE) model

\section{Descriptions of each element}

Six key elements of the Fieldbased Chemistry Experiment (FCE) model
Pre-service science teachers take initiative to organize and participate in the class as both students and teachers who work together to achieve common goals.

Theoretical learning related to experiments are primarily be learned at home before class. During class, pre-service science teachers will reconfirm what they have learned by conducting experiments and solving problems together.

The course instructor plays the role of assistant to create an environment where pre-service science teachers can learn on their own and to use online learning systems to support learning before and after class.

Experiment-based topics related to the secondary curriculum using standard general chemistry experiments will be selected to support pre-service teachers to learn about curriculum topics. As a result of participating in the course, pre-service science teachers will cultivate comprehensive skills such as experimental theories, laboratory safety, experimental design, equipment operation, and experiment-based class guidance to instruct an experiment-based class.

Pre-service science teachers will perform a series of activities needed for actual experiment-based class teaching, including thorough curriculum analysis, reorganization of experiments, development of class materials, and preliminary experiments.

In this section, we focus attention to document and describe the actual practical implementation process for using the FCE model in the general chemistry classroom. This is done to provide researchers and instructors with a practical example for how to conduct the flipped learning model in the university level general chemistry class. In the description of the implementation, we offer discussion of the pros and cons for the instructor and student. Next, we share findings from analysis of student documents developed in the implementation of the lesson, along with interview and questionnaire responses, to discuss 
some benefits and limitations of implementing the FCE model with regards to students' learning about content and pedagogy.

\subsection{Development of FCE Model}

\subsubsection{Development Direction of FCE Model}

Drawing from previous work literature on teaching and learning strategies, we share the key elements of the FCE model that was developed and implemented. The FCE model for pre-service science teachers was established by drawing from previous research and includes six key elements (see Table 3).

\subsubsection{Class Design of FCE Model}

The FCE model was developed to implement student-centered, self-guided learning and to cultivate science teachers' skills in leading chemistry experiments. This model was performed by dividing students into "students in charge (teacher students)" and "students in class (learner students)". The student in charge of the class prepares the class and plays the role of the teacher, and the student participating in the class plays the role of the student. Experimental classes require both theoretical learning and experimentation related to experiments, but there is a huge time constraint to satisfy them all.

Therefore, in the FCE model, where flipped learning is applied, the students participating in the class could learn the knowledge necessary to perform the theory and actual experiment related to the investigation at home before the experiment class. They completed the experimental task in each group during the class. The pre-learning materials were reconstructed by the students in charge of the class, not the instructor.

Likewise, the students who participated in class could freely select the contents of their experiments. Cooperative learning is a method in which learners learn together with their peers to achieve a common goal. Among the various cooperative learning methods, the jigsaw model is a learning method in which students' learning contents are arranged like a jigsaw puzzle so that each student has some information to perform a task and is dependent on each other.

In the FCE model, the jigsaw model was brought to the group activities of the students participating in the class, and the activities were divided into expert group activities and experimental group activities. By assigning individual roles to group activities through expert group activities, they participated in the class with a sense of responsibility, enhanced interdependence, prevented free-riding, and made practical discussion activities possible. Figure 2 shows the class design for the FCE model based on flipped and cooperative learning. 


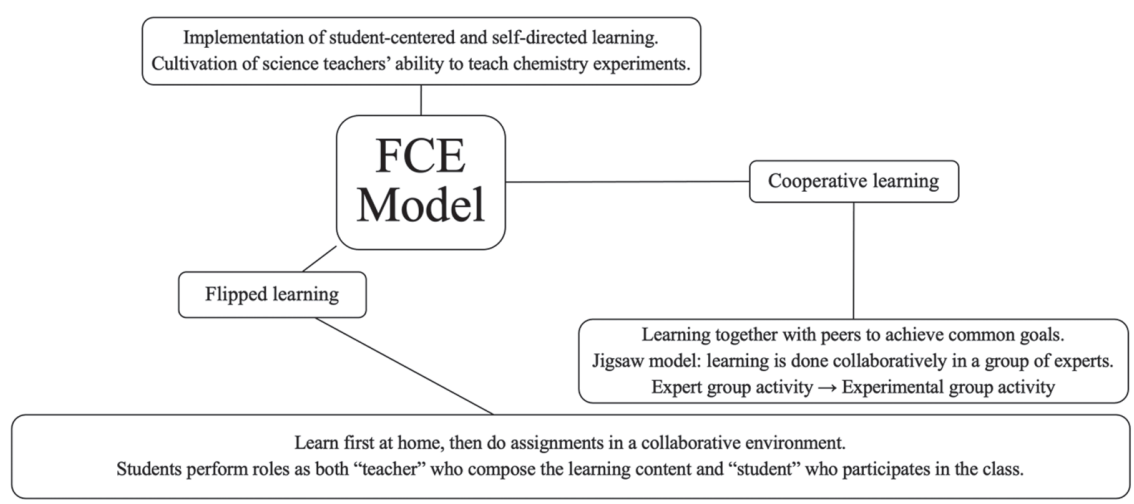

FIGURE 2 Class design for FCE model based on flipped and cooperative learning

\subsection{Application of FCE Model}

The content topic of the general chemistry lab class where the FCE model was applied was selected because it was part of the secondary education general chemistry lab standard curriculum of the university. In particular, it was chosen because it was likely that pre-service science teachers who did not major in chemistry could sufficiently instruct chemistry experiments in the educational field. After forming the group before class, the instructor loaded all the activity sheets on the LMS, and the students in charge analyzed the secondary curriculum related to the experiment-based topic to be held every week and developed and uploaded the preliminary experiment and final class materials. After the class, the instructor interacted with students by providing feedback on the activities of the students on the LMS. Table 4 shows the step-by-step activities of FCE model. Step-by-step activities in the FCE model refers to specific actions performed by the instructor, students in charge, students participating in class before, during and after class.

Students in class wrote preliminary reports using the loaded class materials, divided the group members into expert group activities in each field, and then returned to their own group from this class to share their roles and conducted experiments in cooperation. After sufficient discussion within or between groups and Q\&A with the instructor, a result report was prepared and uploaded into the LMS. While the students in class did expert group activities, group experiment activities, and writing result reports, students in charge guided and observed each step of the class, explaining what students in class were not able to understand in expert group activities and helping them when having difficulties in the experiment. They also helped write result reports when necessary. Students' learning processes, finding of difficulties, and cooperative 
TABLE 4 Step-by-step activities of FCE model

\begin{tabular}{|c|c|c|c|c|}
\hline & Step & & Activity & \\
\hline & & Instructor & $\begin{array}{l}\text { Student in } \\
\text { charge } \\
\text { (teacher role) }\end{array}$ & $\begin{array}{l}\text { Student in } \\
\text { class } \\
\text { (student role) }\end{array}$ \\
\hline \multirow[t]{4}{*}{ Before class } & $\begin{array}{l}\text { Pre-learning } \\
\text { (online) }\end{array}$ & $\begin{array}{l}\text { Dividing groups } \\
\text { and handing } \\
\text { out learning } \\
\text { materials }\end{array}$ & $\begin{array}{l}\text { Analyzing } \\
\text { secondary } \\
\text { curriculum } \\
\text { and textbooks } \\
\text { according to } \\
\text { each subject of } \\
\text { general chemis- } \\
\text { try experiment }\end{array}$ & \\
\hline & $\begin{array}{l}\text { Drafting } \\
\text { material } \\
\text { (online) }\end{array}$ & $\begin{array}{l}\text { Providing feed- } \\
\text { back for drafted } \\
\text { instructional } \\
\text { materials }\end{array}$ & $\begin{array}{l}\text { Drafting instruc- } \\
\text { tional materials }\end{array}$ & \\
\hline & $\begin{array}{l}\text { Preliminary } \\
\text { lab (offline) }\end{array}$ & $\begin{array}{l}\text { Guiding } \\
\text { preliminary } \\
\text { experiment }\end{array}$ & $\begin{array}{l}\text { Conducting } \\
\text { preliminary } \\
\text { experiment }\end{array}$ & \\
\hline & $\begin{array}{l}\text { Preparing } \\
\text { materials } \\
\text { (online) }\end{array}$ & & & $\begin{array}{l}\text { Writing prelimi- } \\
\text { nary reports }\end{array}$ \\
\hline \multirow[t]{4}{*}{ During class } & Introduction & $\begin{array}{l}\text { Giving guidance } \\
\text { and checking } \\
\text { preliminary } \\
\text { reports }\end{array}$ & & \\
\hline & Expert group & & $\begin{array}{l}\text { Teaching and } \\
\text { observation }\end{array}$ & $\begin{array}{l}\text { Expert group } \\
\text { activities }\end{array}$ \\
\hline & Experiment & & & $\begin{array}{l}\text { Group experi- } \\
\text { mental activities }\end{array}$ \\
\hline & Reporting & & & $\begin{array}{l}\text { Writing result } \\
\text { reports }\end{array}$ \\
\hline After class & $\begin{array}{l}\text { Feedback } \\
\text { (online) }\end{array}$ & $\begin{array}{l}\text { Providing and } \\
\text { giving feedback }\end{array}$ & & \\
\hline
\end{tabular}


processes were recorded in certain forms of formatting throughout the course. These activities helped the teachers understand students who participate in experiment-based classes and to understand and perform the role of science teachers in experiment-based classes.

\subsection{Pre-service Teachers' Perceptions of Model Suitability}

The results of the FCE model suitability survey for pre-service science teachers who took general chemistry experiment classes where the FCE model was applied are shown in Figure 3. The FCE model showed a high overall degree of suitability in terms of learner-centered learning, flipped learning, cooperative learning, chemistry lab instructional skills cultivation, and appropriateness for teacher education programs. The pre-service teachers recognized the FCE model as an appropriate education program for learner-centered training based on flipped learning and cooperative learning and for chemistry experiment teaching skills.

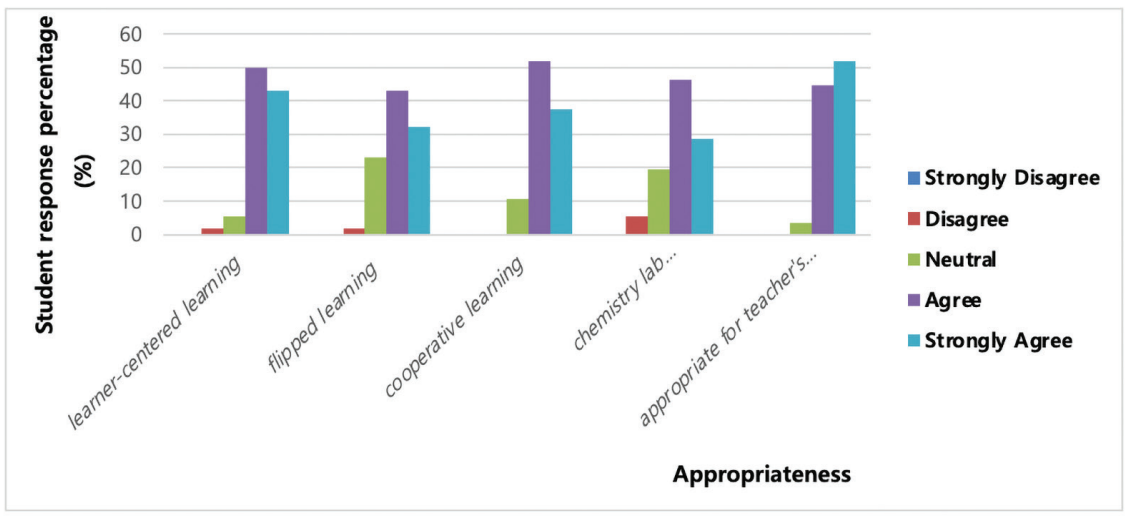

FIGURE 3 Survey responses from 56 students about suitability of FCE model

\subsection{Student Perceptions about the Stepwise Activities Experienced during the FCE Model}

Table 5 shows the response results of the Likert scale questions about whether the step-by-step activities of the FCE model represented in Table 4 are helpful in cultivating the ability to teach chemistry experiments. The average value of the 'preliminary experiment' was very high at 4.63. The preliminary experiment is an activity experienced in the field as an actual teacher. A preliminary experiment allows students to conduct the whole process of the experiment in advance, and they can identify any problems that may arise before class. 
Through this, pre-service teachers will be able to guide students with confidence in the experiment class. Then, given that the average value of writing result reports, class material development, group experimental activity, class guidance, and writing observation reports was high at 4 points, pre-science teachers found that step-by-step activities of the FCE model are helpful in cultivating the ability to teach chemistry experiment.

TABLE 5 Effects of stepwise activities of FCE model $(N=56$, duplicates allowed $)$

\section{Activity}

Preliminary experiment

Writing result reports

Developing instructional materials

Group experimental activities

Class instruction and writing observation reports

Analyzing curriculum and textbook

Writing preliminary reports

Expert group activities
Likert mean value

4.63

4.18

4.16

4.16

4.02

3.82

$3 \cdot 77$

$3 \cdot 30$

\subsection{Student Perceptions about Anticipated Benefits of the FCE Model}

Figure 4 below shows the response results of the narrative questions asking what kind of help students expect to obtain when they become a teacher due to the general chemistry experiment class to which the FCE model is applied. Most of the respondents answered that it was the acquisition of student guidance abilities, and the acquisition of operational skills throughout the experiment class also showed a high response frequency.

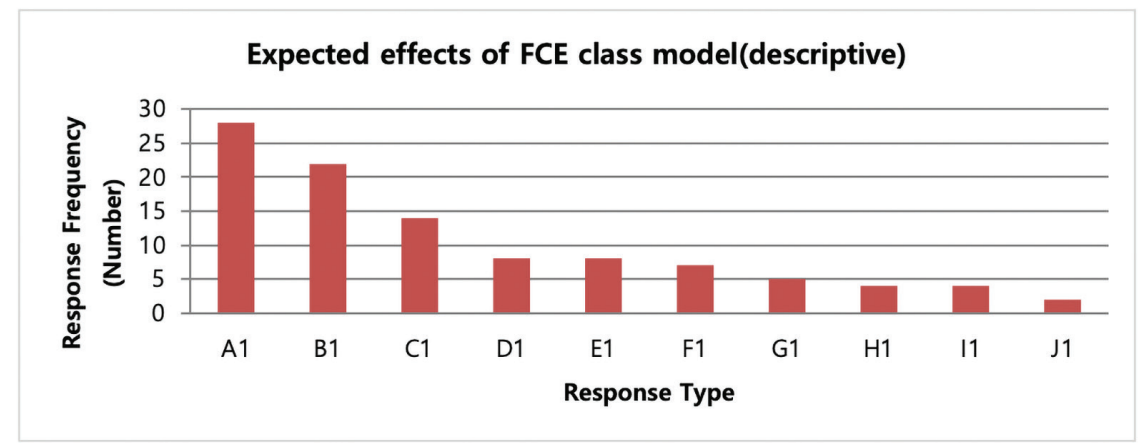




\begin{tabular}{|ll|}
\hline A1 & \multicolumn{1}{c|}{ Response Type } \\
B1 & acquisition of student guidance abilities \\
C1 & acquisition of operation skills of lab equipment \\
D1 & acquisition of knowledge of experimental principles \\
E1 & acquisition of performance skills of preliminary experiments \\
F1 & acquisition of knowledge of laboratory safety \\
G1 & acquisition of ability to cope with unexpected situations acquisition \\
H1 & of ability to reconstruct the content of the experiments acquisition \\
I1 & of student assessment skills \\
J1 & acquisition of ability to improve experiments \\
\hline
\end{tabular}

FIGURE 4 Expected effects of FCE model (descriptive)

This is consistent with the purpose of developing the field-based FCE model for cultivating the ability to teach chemistry experiment, and it is judged that pre-service teachers will not have much difficulty in teaching experiment class based on what they learn when they become real teachers.

Table 6 shows the results of classifying the response results of the narrative questions asking about the strengths of the FCE model according to the answer type and analyzing the response frequency. Pre-service science teachers responded the most to classes that could be used in the field as an advantage of the FCE model. Most of the opinions were that they acquired useful teaching skills in the field by directly performing a series of processes performed by teachers in field-based chemistry experiments. Next, they mentioned the student-centered class format in which the teacher's role is minimized, and students freely organize and act on the class contents as an advantage of the FCE model. 
TABLE 6 Benefits of FCE model $(N=56$, duplicates allowed $)$

Response type
Response frequency

(number)
Classes that can be used in the field

20

Self-directed, student-centered classes

16

12

Classes where various teaching methods can be experienced

Classes to develop the ability to reconstruct experiment $\quad 12$ classes

Fun classes

A variety of experiment-based classes

Classes to learn the ability to operate laboratory equipment

Classes to learn the importance of preliminary experiment-based activities

Classes with meaningful textbook analysis activities $\quad 2$

Classes experimental principles can be learned $\quad 2$

Total

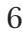

4

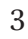

2

79

\subsection{Student Opinions about the Improvement of Limitations to the FCE Model}

Table 7 below shows the results of classifying the response results of the narrative questions asking for opinions on the limitations of the FCE model according to response types and analyzing the response frequency. The most common opinion was that the amount of learning was greater than class hours, followed by the opinion that improvement was needed to make the expert group activities more active. In addition, there were opinions about the improvement of the laboratory environment such as laboratory equipment and reagents. There is an opinion that students want to hear the lecture directly from the instructor, and they want a form in which the students can lecture the contents of the class. Reflecting the opinions of these pre-service teachers, it is necessary to integrate several experimental subjects to reduce the amount of learning by adjusting the overall experimental subjects, or to increase the number of teaching hours by opening a 1-credit course into a 3-credit course. To increase the effectiveness of the expert group activity, the lecture method that students in charge or students in class give a lecture by improving the roles of teachers 
Response type

Response frequency

(number)

Improvement in learning amount

Improvement of expert group activities

Improvement lab environment

7

Improvement the role of instructor and students

other

Total

(student in charge) and students (student in class) can partially be applied. Additionally, improvement of the laboratory environment should be supported for smooth experimental activities.

\section{Conclusions and Implications}

In this study, the effects of developing and applying the FCE model for cultivating pre-service science teachers' chemistry experiment teaching ability was examined. The FCE model was developed for cultivating pre-service science teachers' ability to guide chemistry experiment classes. The FCE model is a field-based chemistry experiment teaching model, and the teaching method was devised by combining the teaching techniques of flipped learning and cooperative learning. In addition, students were allowed to compose the class content and methods themselves, and it was designed so that pre-service science teachers could directly experience the series of processes that science teachers perform for experiment-based classes. The role of the instructor was minimized to playing the role of a learning facilitator, and the learners participated in the class by playing the roles of either students in charge, who served as teachers, or students in class, who served as students. Students in charge developed instructional materials through curriculum and textbook analysis, conducted preliminary experiments, and observed and guided students, so that they could naturally perform the role of teaching the lab class as a teacher. Students in class studied the instructional materials created by the students in charge in advance, and then conducted expert group activities and experimental group activities during the experiment-based class so that they could think about the difficulties of the experiment or instructional matters from the student's point of view. 
The developed FCE model was applied to a general chemistry experiment course for pre-service science teachers. Pre-service science teachers judged that the developed FCE model was suitable in terms of learner-centered learning, flipped learning, cooperative learning, development of chemistry experiment teaching skills, and subjects at a teachers' college. They judged that the stepwise activities of the FCE model were helpful in cultivating the ability to instruct chemistry experiment classes. Pre-service teachers agreed that the class being able to be used in the field was an advantage of the FCE model, and they mentioned that the amount of learning was greater than the number of hours of education as an improvement point for the FCE model. Moreover, through the FCE model, pre-service science teachers gained knowledge of experimental principles, laboratory safety, and operation of laboratory equipment. They were also trained to reconstruct the content of experiments necessary for lab teaching, improve experimental methods, and conduct preliminary experiments. In addition, it was confirmed through the results of the activities, teacher observation journals, interviews, and questionnaire analysis that students acquired evaluation abilities, teaching abilities, and the ability to cope with unexpected situations.

In conclusion, it is not only important to improve the scientific inquiry ability of pre-service science teachers through general chemistry experiment classes, but the purpose of the colleges of education should be to educate preservice science teachers so that they can go to the actual educational field and properly lead experiment classes. Therefore, it is necessary to extend the FCE model to the overall education in colleges of education so that pre-service science teachers can have practical experimental instructional skills. Education should be provided so that even pre-service teachers who do not major in chemistry can teach chemistry experiments without difficulty. In the future, follow-up studies will also be conducted to construct a competitive and distinct curriculum for colleges of education so that students can acquire competence as science teachers by ensuring the appropriateness of the educational content and methods of not only experiment-based subjects but also other subjects relevant for pre-service science teachers.

\section{Limitations}

The results of this study were obtained from only one semester of teaching in a limited area. Further studies would require more participants over a longer period of application of the FCE model. Follow-up studies on the pre-service science teachers who participated in this study when they become teachers 
and face actual classrooms would be helpful in validating the results of the FCE model.

$\begin{array}{ll} & \text { Abbreviations } \\ & \\ \text { CK } & \text { Content Knowledge } \\ \text { FCE } & \text { Field-based Chemistry Education } \\ \text { LMS } & \text { Learning Management System } \\ \text { PBL } & \text { Project Based Learning } \\ \text { PCK } & \text { Pedagogical content knowledge }\end{array}$

\section{Ethical Considerations}

Approval to conduct this study was granted by the Kyungpook National University Ethics Review Board. The data collected from this project were obtained with the necessary clearance from the students involved in the study. The names of the participants used in this study are all pseudonyms.

\section{Publication Consideration}

This manuscript is adapted in part from research shared in an unpublished doctoral degree thesis: Bae, S. (2018). Development and application of FCE (Field-based Chemistry Experiment) model for improvement of pre-service science teachers' chemistry experiment teaching ability. Doctoral Dissertation, Kyungpook National University. Daegu, South Korea.

\section{About the Authors}

Sung Woo Bae is a teacher in Daegu Dongbu Highschool in Daegu, Republic of Korea. He received his bachelor's degree in chemistry education and a master's degree and doctoral degree in Science Education from the Kyungpook National University. His research focuses on the careers of pre-service science teachers and the development of educational models for experimental training of preservice science teachers. Currently he is working to develop and implement science teaching at the high school level that motivates and interests students to learn science. 
Jae Hwan Lee is a lecturer in Department of Chemistry Education at Kyungpook National University in Daegu, Republic of Korea. She received her bachelor's and master's degree in Chemistry (Analytical Chemistry) and doctoral degree in Science Education from the Kyungpook National University. Her research focuses on Chiral separation using HPLC (high performance Liquid Chromatography) and developing class model for chromatography using smart devices in secondary school. She is particularly interested in providing pre-service chemistry teachers with opportunities to deal with smart devices in chemistry lab and other issues.

Jongseok Park is a Professor of Department of Chemistry Education, Teachers' College Kyungpook National University. He has been engaged in science teaching and research since 1990 and is currently teaching integrated sciences and education courses for preservice teachers at undergraduate and graduate levels.

\section{References}

Bales, B. L. (2007). Teacher education reform in the United States and the theoretical constructs of stakeholder mediation. International Journal of Education Policy \& Leadership, 2(6), 1-13.

Bokosmaty, R., Bridgeman, A., \& Muir, M. (2019). Using a partially flipped learning model to teach first year undergraduate chemistry. Journal of Chemical Education, 96, 629-639.

Cho, D. S. (2004). Rethinking teacher education systems: Challenges, changes and future directions. The Journal of Elementary Education, 17(2), 499-516.

Choi, J. B., \& Kim, E. G. (2015). Developing a teaching-learning model for flipped learning for institutes of technology and a case of operation of a subject. Journal of Engineering Education Research, 18(2), 77-88.

Choi, Y. J., \& Ahn, M. K. (2001). The effects of jigsaw II expert groupings on student's knowledge, inquiry ability and attitudes at elementary school science study. The Korean Society of Elementary Science Education, 2O(2), 177-186.

Davies, R. S., Dean, D. L., \& Ball, N. (2013). Flipping the classroom and instructional technology integration in a college-level information systems spreadsheet course. Education Technology Research and Development, 61, 563-580. doi: 10.1007/ s11423-013-9305-6.

Dixon, M. D. (2010). Creating effective student engagement in online courses: What do students find engaging? Journal of the Scholarship of Teaching and Learning, 10(2), 1-13. 
Fautch, J. M. (2015). The flipped classroom for teaching organic chemistry in small classes: is it effective? Chemistry Education Research and Practice, 16, 179-186.

Ferk Savec, V., \& Wissiak Grm, K. S. (2017). Development of chemistry pre-service teachers during practical pedagogical training: Self-evaluation vs. evaluation by school mentors. Acta Chimica Slovenica, 64(1), 63-72.

Hawkes, S. J. (1989). What chemistry do our students need to learn? Journal of Chemical Education, 66(10), 831-832.

Hawkes, S. J. (1992). Why should they know that? Journal of Chemical Education, 69, 178-181.

Hawkes, S. J. (2007). What chemistry to teach engineers? Journal of Chemical Education, $77(3), 321-326$.

Hofstein, A. (2004). The laboratory in chemistry education: Thirty years of experience with developments implementation, and research. Chemistry Education Research and Practice, 5(3), 247-264.

Hwang, Y. L., Park, Y. B. (2011). Effect of jigsaw III cooperative learning on science achievement and learning attitude of middle school female students. Journal of Science Education, 35(1), 91-101.

Jamaludin, R. \& Osman, S. Z. (2014). The use of a flipped classroom to enhance engagement and promote active learning. Journal of Education and Practice, 5(2), 124-131.

Jeon, Y. J., \& Yoon, M. B. (2016). The application of science education lecture for preservice teacher using teaching-learning method based on flipped learning. Journal of the Korean Association for Science Education, 36(3), 499-507.

Kim, B. K. (2014). Development of flipped classroom model for teaching profession courses. The Journal of Educational Research, 12(2), 25-56.

Kim, H. M., \& Shim, K. C. (2009). Study on properties of teaching behaviors of science student-teachers: Presentation of learning objectives, delivery of subject contents and performance of teaching and learning, Biology Education, 37(3), 363-375.

Kim, J. H., \& Lee, K. Y. (2006). Investigation of the earth science teacher education programs in the college of education and their improvement plans. Journal of the Korean Earth Science Society, 27(4), 390-40o.

Kim, N. I., Chun, B. A., \& Choi, J. I. (2014). A case study of flipped learning at college: Focused on effects of motivation and self-efficacy.Journal of Educational Technology, $30(3), 467-492$.

Kim, Y. M., Park, J. W., Park, J. S., Lee, H. N., \& Kim, Y. S. (2010). Science teachers' perceptions and needs for courses in science education subjects for science teacher preparation program in Korea. Journal of the Korean Association for Science Education, $30(6), 785^{-798 . ~}$

Lazarowitz, R., Hertz-Lazarowitz, R., \& Baird, J. H. (1994). Learning science in a cooperative setting: Academic achievement and affective outcomes. Journal of Research in Science Teaching, 31(10), 1121-1131. 
Lee, B. H., \& Lee, H. C. (2016). The effects of science lesson with the application of flipped learning on science academic achievement and scientific attitude. The Korean Society of Elementary Science Education, 35(1), 78-88.

Lee, D. Y. (2013). Research on developing instructional design models for flipped learning. The Journal of Digital Policy \& Management, 11(12), 83-92.

Lee, J. H., Moon, Y. L., Oh, E. J., \& Kim, J. B. (2016). Development and application of practical curricula for pre-service science teachers using learning assistant program. School Science Journal, 10(1), 68-82.

Lee, J. Y., Park, S. H., Kang, H. J., \& Park, S. Y. (2014). An exploratory study on educational significance and environment of flipped learning. Journal of Digital Convergence, 12(9), 313-323.

Lee, Y. J., \& Im, S. M. (2011). An analysis of pre-service science teachers' reflective thinking about scientific experiment in experimental journal writings. Journal of the Korean Association for Science Education, 31(2), 198-209.

Lucena, F. J. H., Belmonte, J. L., Cabrera, A. F., Torres, J. M. T., \& Sánchez, S. P. (2020). Academic effects of the use of flipped learning in physical education. International Journal of Environmental Research and Public Health, 17, 276, https://doi.org/10.339o/ ijerph17010276.

Mavhunga, E. (2014). Improving PCK and CK in chemistry pre-service teachers. In M. Askew, H. Venkat, M. Rollnick \& J. Loughran (Eds.), Exploring Content Knowledge for Teaching Science and Mathematics: Windows into teacher thinking (pp. 29-49). Abington, UK: Routledge.

Munir, M. T., Baroutian, S., Young, B. R., \& Carte, S. (2018). Flipped classroom with cooperative learning as a cornerstone. Education for chemical engineers, 23, 25-33.

Noh, A. R., Choi, H. K., \& Cung, S. J. (202O). Pre-service secondary teachers' perceptions of good science teaching and evaluation of their own teaching. Journal of Science Education, 25, 37-52.

Pak, M. S., Lyovkin, A. N., \& Sanger, M. J., Brincks, E. L., \& Phelps, A. J. (2001). A comparison of secondary chemistry courses and chemistry teacher preparation programs in Iowa and Saint Petersburg, Russia. Journal of Chemical Education, 78(9), 1275-1280.

Park, J. Y., \& You, H. S. (2001). The effects of jigsaw cooperative learning strategy applied to the middle school science class. Journal of the Korean Association for Science Education, 21(3), 635-647.

Rodriguez-Becerra, J., Cáceres-Jensen, L., Diaz, Tatiana, Druker, S., Bahamonde-Pedilla, V., Pernaa, J., \& Aksela, M. (2020). Developing technological pedagogical science knowledge through educational computational chemistry: a case study of preservice chemistry teachers' perceptions. Chemistry Education Research and Practice, 21, 638-654.

Romero-García, C., Buzón-García, O., \& Touron, J. (2018). The flipped learning model in online education for secondary teachers. Journal of Technology and Science Education, 9(2), 109-121. 
Rusmansyah, Yuanita, L., Ibrahim, M., Isnawati, \& Prahani, B. K. (2019). Innovative chemistry learning model: Improving the critical thinking skill and self-efficacy of pre-service chemistry teachers. Journal of Technology and Science Education, 9(1), 59-76.

Schnoebelen, C., \& Towns, M. H. (2018). Design and evaluation of a one semester general chemistry course for undergraduate life science majors. Journal of Chemical Education, 95(5), 734-740.

Schoon, K. J., \& Sandoval, P. A. (1997). The seamless field experience model for secondary science teacher preparation. Journal of Science Teacher Education, 8(2), 127-140.

Seery, M. K. (2015). Flipped learning in higher education chemistry: emerging trends and potential directions. Chemistry Education Research and Practice, 16, 758-768.

Sharan, Y. (2010). Cooperative learning for academic and social gains: Valued pedagogy, problematic practice. European Journal of Education, 45(2), 300-313.

Shim, K. C. (2010). Study on initial teacher training programs for science teachers in England: Roehampton University, England. Biology Education, 38(3), 492-506.

Teo, T. W., Tan, K. C. D., Yan, Y. K., Teo, Y. C., \& Yeo, L. W. (2014). How flip teaching supports undergraduate chemistry laboratory learning. Chemistry Education Research and Practice, $15,55^{\circ}-567$.

Toqeer, R. (2013). Flipped classroom concept application to management and leadership course for maximizing the learning opportunities. The Business \& Management Review, 3(4), 137-144.

Weld, J. D., \& French, D. P. (2001). An undergraduate science laboratory field experience for pre-service science teachers. Journal of Science Teacher Education, 12(2), 133-142.

Wheeldon, R. (2017). Improving preservice chemistry teachers' content knowledge through intervention activities. International Journal of Science Education, 39(9), 1238-1261.

Widhiyanti, T., Treagust, D. F., Mocerino, M., \& Vishnumolakala, V. (2017). Content knowledge development in a chemistry teacher preparation program: A current potentials and challenges. AIP conference proceedings, 1868, 030016, https://doi .org/10.1063/1.4995115.

Yang, C. H., Lee, J. H., \& Noh, T. H. (2014). The characteristics of lesson planning of pre-service secondary science teachers. Journal of the Korean Association for Science Education, 34(2), 187-195.

Yurumezoglu, K., \& Oguz-Unver, A. (2011). A suggestion for an experiment that integrates the teaching of science with everyday life: "Why are the seas blue?". Science Activities, 48(2), 43-48.

Zemel, Y., Shwartz, G., \& Avargil, S. (2021). Preservice teachers' enactment of formative assessment using rubrics in the inquiry-based laboratory. Chemistry Education Research and Practice, 22, 1074-1092. 